\title{
Пронин А.Ю. \\ Кадровое обеспечение научно-исследовательских организаций Минобороны России гражданскими специалистами
}

Российская академия ракетных и артиллерийских наук (Россия, Москва)

doi: $10.18411 / \mathrm{j}-08-2021-51$

\section{Аннотация}

Рассмотрена проблема комплектования научно-исследовательских организаций Минобороны России оборонно-ориентированными гражданскими научными кадрами. Предложено направление решение данной проблемы, которое заключается в подготовке гражданских специалистов для организаций Минобороны России в системе «высшее учебное заведение - базовая кафедра - базовая организация». Рассмотрены цели и основные задачи подготовки оборонно-ориентированных кадров на базовых кафедрах.

Ключевые слова: целевое обучение, гражданский специалист, базовая кафедра, базовая организация, Минобороны России.

\section{Abstract}

The problem of recruiting research organizations of the Russian Ministry of Defense with highly qualified defense-oriented scientific personnel is considered. A direction for solving this problem is proposed, which consists in training civilian specialists for organizations of the Ministry of Defense of Russia in the system "higher educational institution - base department - base organization". The goals and main tasks of training defense-oriented personnel at the basic departments are considered.

Keywords: targeted training, civilian specialist, base department, base organization, Ministry of Defense of Russia.

Характер возникновения различных межгосударственных конфликтов, наблюдаемых в последнее время, свидетельствует о повышении значения и роли оборонного потенциала государства как для сохранения национального суверенитета и экономического развития, так и для управления качеством и правовыми нормами международных отношений с ведущими странами мира [1-4]. Увеличивается количество государств, которым становятся доступны разработка и закупка инновационных образцов вооружения, военной и специальной техники, с помощью которых они силовыми методами могут решать возникающие политические, территориальные и иные спорные проблемы. Растут масштабы международного терроризма, меняются формы и методы ведения войн [5-7]. Увеличение мощности и дальности поражения нового оружия способствуют росту опасности распространения возникающих конфликтов на новые территории.

В период до 2030 года уровень существующих и потенциальных военных опасностей и угроз для Российской Федерации может повыситься в значительной степени, поскольку он связан с борьбой развитых стран за трудовые и топливноэнергетические ресурсы, за доминирование на национальных и мировых рынках, за жизненные пространства и территории. Для достижения этих и других целей будут активно наращиваться и использоваться накопленный оборонный потенциал, результаты инновационных достижений науки, технологий и техники.

Бесспорными предтечами инновационной деятельности являются наука и образование (подготовка научных кадров), в том числе их состояние и тенденции развития. Однако, в последнее время проблема подготовки кадров для научно- 
исследовательских организаций (НИО) Минобороны России, проводящих оборонноориентированные инновационные исследования и разработки, стоит особенно остро.

Основная причина кроется в следующем. В течение ряда лет НИО Минобороны России комплектовались выпускниками высших военно-учебных заведений, проходивших обучение по специальным программам. Гражданские специалисты целенаправленно для военных НИО вообще не готовились. В результате проведенных кадровых реформ в течение 2006-2015 гг. во многих НИО Минобороны России количество научно-исследовательских отделов было сокращено более чем в 1,5 раза, количество научных сотрудников сократилось в 2-3 раза, при этом количество направлений исследований увеличилось на 10\%, и в последние годы, когда активизировались исследования по передовым инновационным направлениям, проблема кадров в НИО Минобороны России значительно обострилась [8].

Решение данной проблемы видится в организации системы подготовки высококвалифицированных оборонно-ориентированных гражданских специалистов в ведущих высших учебных заведениях.

Представляется, что подготовку гражданских специалистов для НИО Минобороны России целесообразно осуществлять в системе высших учебных заведения на базовых кафедрах путём государственного заказа, согласованного с органами военного управления.

Наша страна имеет огромный опыт подготовки научных кадров в системе высшей школы. Лауреат Нобелевской премии Петр Леонидович Капица еще в 1946 году в письме Председателю Совета народных комиссаров СССР Иосифу Виссарионовичу Сталину впервые сформулировал принципы системы образования на базовых кафедрах [9]:

— тщательный отбор одаренных и склонных к творческой работе представителей молодежи;

- воспитание молодежи с первых же шагов в атмосфере технических исследований и конструктивного творчества;

- индивидуальный подход к отдельным студентам с целью развития их творческих способностей при отсутствии имеющихся сейчас в высших учебных заведениях перегрузке второстепенными предметами по общей программе и механического заучивания (следствие необходимости массового обучения);

- непосредственное участие в обучении ведущих научных работников в тесном контакте с ними в творческой обстановке.

В основе идеи базовой кафедры лежит желание делиться своим опытом, знаниями, идеями с коллегами по профессии. Чем раньше студенты начнут осознавать себя частью профессии, и чем глубже будет их понимание серьезности сделанного выбора, тем качественнее будет образование выпускников [10].

В настоящее время базовые кафедры набирают все большую популярность, причем в самых разных отраслях. Они есть у банков (Сбербанк, ВТБ, ВЭБ), ІТкомпаний (SAP, ABBYY, Parallels, "Яндекс"), страховщиков ("Ингосстрах"), нефтяников и энергетиков (ЛУКОЙЛ, холдинг МРСК), а также у машиностроителей, адвокатов и даже у «большой четверки» аудиторских компаний. Две базовые кафедры созданы на ПАО «НПО «Алмаз-Антей» имени академика А.А. Расплетина [8].

За максимальное приближение обучения к реальному сектору экономики, к предприятиям и научным организациям, в которых будут трудиться выпускники вуза, путем создания базовых кафедр уже в течение ряда лет выступают ведущие вузы страны: МГТУ имени Н.Э. Баумана, МАИ, МЭИ, РТУ МИРЭА, МИСиС, ЮжноУральский государственный университет и ряд других.

В интересах Минобороны России основная цель базовой кафедры - подготовка высококвалифицированных оборонно-ориентированных гражданских специалистов, владеющих необходимыми компетенциями для самостоятельной научноисследовательской и иных видов деятельности по профилю образовательной деятельности кафедры. 
Исходя из цели основными задачами базовой кафедры должны быть следующие:

- подготовка востребованных на рынке труда высококвалифицированных оборонно-ориентированных кадров для НИО Минобороны России, владеющих необходимыми компетенциями для самостоятельной научно-исследовательской деятельности, на базе основных образовательных программ среднего, высшего и дополнительного профессионального образования, профессионально-ориентирующих и других программ подготовки по профилю образовательной деятельности базовой кафедры;

- проведение фундаментальных и прикладных оборонноориентированных научных исследований, научно-исследовательских и опытно-конструкторских работ, инновационной деятельности научнопедагогических работников и обучающихся, увеличение объема и эффективности научных исследований, расширение их тематики;

- интеграция науки и образования путем использования результатов научных исследований в учебном процессе и установления взаимовыгодных связей между образовательными, научными, конструкторскими учреждениями, предприятиями и организациями как единой коллективной системы получения и применения знаний и технологий;

- публикация научных результатов в периодических и специальных научных изданиях, участие в семинарах и конференциях;

— создание и развитие научных школ;

- планирование, организация и контроль повышения квалификации профессорско-преподавательского состава.

В результате освоения специальной программы обучения на базовой кафедре у выпускника формируются общекультурные, общепрофессиональные и профессиональные компетенции, т.е. способности применять знания, умения и личные качества в соответствии с задачами профессиональной деятельности.

Планируется, что выпускники базовых кафедр, подготовленные «целевым порядком» могут быть распределены в НИО Минобороны России, в органы военного и государственного управления, оборонно-ориентированные предприятия и организации (в научные подразделения, подразделения программно-целевого планирования, управления качеством, организационно-плановые и т. п.).

1. $\quad$ Barnett T.P. Great Powers: America and the World after Bush. Putnam Publishing Group, 2009. 284 p.

2. Fukuyama F. State-Building: Governance and World Order in the 21st Century. Cornell University Press, 2004. 436 p.

3. Волков А.Д. Военно-экономическая безопасность Российской Федерации // Актуальные проблемы гуманитарных и естественных наук. 2014. № 4-2. С. 28-30.

4. Викулов С.Ф. и др. Кадровое обеспечение обороноспособности страны // Национальные интересы: приоритеты и безопасность, 2017, т. 13, вып. 1, стр. 4-19.

5. Викулов С.Ф., Коновалов В.Б., Хрусталёв Е.Ю. Финансовые и экономические войны в эпоху сетевого мироустройства // Политематический сетевой электронный научный журнал КубГАУ. 2015. № 7. С. 1581-1597.

6. Слипченко В.И. Войны шестого поколения. Оружие и военное искусство будущего. М.: Вече, 2002. 384 c.

7. Arquilla J., Ronfeldt D.F. Networks and Netwars: The Future of Terror, Crime, and Militancy. RAND Corporation, 2001. 217 p.

8. Боков С.И., Гладышевский В.Л., Полярус А.Н. и др. Базовые кафедры при ВУЗах как направление развития кадрового обеспечения научно-исследовательских организаций Минобороны России // Военная мысль. - 2018. № 7. - C.55-65.

9. https://mipt.ru/about/museum/fizteh/historical_review/pismo-kapitsy-stalinu-1946g.php. Дата обращения - 21.07.2021 г.

10. Кунле М. Своя кафедра. [Электронный ресурс] / Web-сайт «КоммерсантЪ» - 2017. - Режим доступа: http://www.kommersant.ru/doc/3086490, свободный. - Загл. с экрана. Дата обращения 12.05.2017 г. 